\title{
FALANDO SOBRE PRESENÇAS-AUSENTES: VIVÊNCIAS DE SOFRIMENTO NO LUTO MATERNO
}

Talking about absent-presences: Experiences of suffering in maternal mourning

Hablando sobre presencias-ausentes: Experiencias de sufrimiento en el luto materno

\author{
Gustavo Alves Pereira de Assis \\ Hinayana Leão Motta \\ Ronaldo Veríssimo Soares \\ Universidade de Rio Verde (UniRV)
}

\begin{abstract}
RESUMO
A morte é um fato cotidiano que também se faz presente na vida de muitas mães. Com o objetivo de compreender as vivências de sofrimento no luto materno, utilizou-se a abordagem qualitativa e o método fenomenológico para o desvelamento dos sentidos desta experiência. Para isso, recorremo-nos à entrevista fenomenológica, gravada e transcrita na íntegra, com quatro participantes. Foram encontrados sete constituintes essenciais, que refletem uma estrutura comum do enlutamento materno, sendo: alterações e dificuldades no viver, desespero, dor, sentimento de arrependimento e culpa, sentimentos negativos despertados pelas lembranças, perda de um modo de existir e perda do sentido do mundo-da-vida. Os resultados apontaram para intenso sofrimento, com repercussões físicas e emocionais. Com a ruptura na habitualidade do ser-mãe, o filho anuncia-se perante o sofrimento, fazendo-se indicativo de uma nova presença: a ausente. A experiência de luto apresentou-se como condição existencial, como um novo modo de ser-com.
\end{abstract}

Palavras-chaves: Maternidade; Morte; Psicologia Fenomenológica.

\begin{abstract}
Death is an everyday fact that is also present in the lives of many mothers. To understand the experiences of suffering in maternal mourning, we used the qualitative approach and the phenomenological method for the unveiling of the senses of this experience. For this, we used the phenomenological interview, recorded and transcribed in full, with four participants. Seven essential constituents were found, which reflect a common structure of the maternal mourning: changes and difficulties in living, despair, pain, feeling of repentance and guilt, negative feelings triggered by memories, loss of a mode of existence, and loss of sense of world-of-life. Results pointed to intense suffering with physical and emotional repercussions. With the rupture in the habitualness of the being-mother, the child is announced before the suffering, being an indicative of a new presence: the absent one. The experience of mourning presented itself as an existential condition, a new way of being-with.
\end{abstract}

Rev. Nufen: Phenom. Interd. | Belém, 11(1), 39-54, jan. - abr., 2019. 
Keywords: Maternity; Death; Phenomenological Psychology.

\section{RESUMEN}

La muerte es un hecho cotidiano que también se hace presente en la vida de muchas madres. Con el objetivo de comprender las experiencias de sufrimiento en el luto materno, se ha utilizado el abordaje cualitativo y el método fenomenológico para el desvelamiento de los sentidos de esta experiencia. Para ello, recurrimos a la entrevista fenomenológica, grabada y transcrita en la íntegra, con cuatro participantes. Han sido encontrados siete constituyentes esenciales, que reflejan una estructura común del duelo materno, que son alteraciones y dificultades en el vivir, desespero, dolor, sentimiento de arrepentimiento y culpa, sentimientos negativos despertados por los recuerdos, pérdida del modo de existir y pérdida del sentido del mundo de la vida. Los resultados apuntaron para el intenso sufrimiento, con repercusiones físicas y emocionales. Con la ruptura en la habilidad del ser madre, el hijo se anuncia ante el sufrimiento, haciéndose indicativo de una nueva presencia: la ausencia. La existencia del luto se presentó como condición existencial, como una nueva manera de ser con.

Palabras claves: Maternidad; Muerte; Psicología Fenomenológica.

Esse momento de se certificar de que a morte está acontecendo é também um muro, um muro daquela relação (...). Chegamos ao muro e não dá para pular ou dar a volta; é preciso olhar e reconhecer que existe essa morte, esse fim.

(A morte é um dia que vale a pena viver, de Arantes [2016, p. $163])$

A pesquisa se debruçará sobre a temática do luto materno. Como recorte, optouse pelas vivências de sofrimento nesta experiência humana. Partir-se-á de uma concepção fenomenológica-existencial do luto, em uma tentativa de compreender esse fenômeno enquanto condição essencialmente humana.

Ao dissertar sobre o luto, a morte nos aparece como fundamento primeiro, visto que este se inaugura a partir de uma perda, de uma ruptura. Na sociedade contemporânea, a temática do processo de morrer é frequentemente negada. Freitas (2013) assevera que não há espaço para a reflexão sobre a morte ou temas correlatos. A autora aponta que a comunidade científica partilha, muitas vezes, dessa negação. Para Kovács (1992), "neste momento em que não há lugar para a morte, é que ela está mais presente, espreitando em todos os cantos" (p.5). Assim, a autora afirma que vida e morte são fenômenos entrelaçados, sendo a morte uma presença constante em todo o desenvolvimento humano.

O morrer é um fato cotidiano, pois não morremos só no último instante de nossa vida, mas todos os dias, conforme Bromberg (2000). Segundo a autora "a morte é a única presença constante na vida. Vive-se, morrendo. Paradoxalmente, é pela extinção da vida - ou seja, por viver - que se morre" (p. 15). Esta perspectiva insere o morrer como um fenômeno

Rev. Nufen: Phenom. Interd. | Belém, 11(1), 39-54, jan. - abr., 2019. 
da e na vida, a considerar que diariamente há "morte" de processos fisiológicos e psicológicos. Aqui, entende-se morte por renovação e ressignificação. Todavia, trata-se de uma contradição cultural, se concebermos a morte como um fenômeno natural do viver e a sua negação no contexto social contemporâneo. Sobre isso, Kovács (1992) explica que existem possibilidades culturais e psicológicas para ocultar a presença da morte na vida, resultando, muitas vezes, em um não-viver, que se assemelha ao morrer. A autora se refere ao morto em vida, para explicitar que o verdadeiro viver requer a consciência do processo de morrer.

Assim, com o falecimento do outro inaugura-se o luto. Esta experiência evoca nossa condição mortal, refletindo a irreversibilidade da morte. Afinal, com o morrer do outro há uma sinalização de nossa própria morte, de nossa finitude e sua impossibilidade de reversibilidade. Em uma concepção fenomenológica-existencial, partindo do paradigma merleau-pontyano, o luto é compreendido como uma condição e experiência existencial. Esse fenômeno é concebido como uma ruptura na relação eu-tu. Essa mudança radical evidencia uma supressão da intercorporeidade, da coexistência. Assim, no luto há uma perda do mundo partilhado, temporoespacialmente, havendo assim uma impossibilidade de atualização (Freitas, 2013; Freitas, 2018; Michel, 2017).

O luto, segundo Freitas, Michel e Zomkowski (2015), enquanto experiência de perda, fala da morte do "nós": o morto em sua corporeidade e o sobrevivente em suas possibilidades de ser, havendo uma perda de si. Para os autores, "o luto é, por conseguinte, do ponto de vista existencial, um modo de reversibilidade quiasmática eu-outro: desapareço em seu desaparecer para que, enfim, um novo mundo se (me) revele" (p. 23). Sendo assim, o que se revela no fenômeno luto é a relação entre o morto e o sobrevivente. Em MerleauPonty (1999), há referência de que somos relação do começo ao fim. Por isso, o luto se apresenta como fenômeno relacional, em que há a morte de um mundo, de uma história, de uma relação.

No que se refere ao luto materno, a corporeidade do filho é abruptamente suprimida. Há uma desaparição do filho, que provoca mudanças no campo existencial da mãe, exigindo novas formas de ser-no-mundo. Na concepção de Merleau-Ponty (1999) "toda ausência é apenas o avesso de uma presença, todo silêncio é apenas uma modalidade do ser sonoro" (p. 448). Para o autor, a ausência se faz presença em seu emergir fenomenal. É nessa perspectiva que o luto a que nos referimos se inscreve.

Essa nova presença reflete uma nova existência, pois, de acordo com Freitas (2013), "a existência será doravante uma presença que se anuncia na ausência" (p. 103). Deste modo, é na ausência que se encontra a presença desse outro, de um filho que se foi. Assim, o luto exige uma ressignificação da relação eu-tu, da relação mãe-filho, constituindose como uma nova presença deste outro, que agora é presença-ausente (Freitas, 2013; Michel, 2017).

Rev. Nufen: Phenom. Interd. | Belém, 11(1), 39-54, jan. - abr., 2019. 
Essa ruptura na relação é geradora de sofrimento, constituindo-se como uma experiência dolorosa. Assim, luto é crise de sentido, resultando em sofrimento psíquico (Freitas, 2013; Freitas, 2018). Ao falar sobre esse sofrimento, sobre essa dor

estamos nos referindo não à dor física produzida pela estimulação de terminações nervosas específicas em sua recepção, mas à dor com sentido, com razão de ser e significado para a nossa subjetividade, com sentimento de pesar, de aflição, tristeza e desgosto. Essa dor é inominável, ela é sentida, vivida (Azevedo \& Barbosa, 2013, p. 55).

A dor aparece como sentido fundamental da experiência de luto, em Freitas et al. (2015) e em Freitas e Michel (2015). Deste modo, o sofrimento é condição do luto, enquanto dor que denota a ruptura da relação dialógica entre mãe e filho. Berten (2010) faz uma reflexão sobre a incomunicabilidade do sofrer. Para ele, o sofrimento encontra-se na esfera do indizível. Partilhamos desta concepção ao entendermos que a dor de perder um filho é indescritível e incomensurável, e, portanto, anuncia-se como impossibilidade de expressão total. É dor inenarrável, apenas sentida.

No tocante às produções científicas sobre o tema, a revisão sistemática sobre a experiência de morte no seio familiar em estudos fenomenológicos de Barbosa, Melchiori e Neme (2011) constatou a baixa frequência de publicações, com ausência de trabalhos até o ano de dois mil e dezesseis, sugerindo que o interesse pela área é recente na literatura latinoamericana. A investigação identificou que, em relação às experiências, significados e enfrentamento do luto, obteve-se oito estudos. As autoras reiteram a necessidade de pesquisas sobre a experiência de perdas por morte no âmbito individual e familiar.

Dados semelhantes foram encontrados na revisão integrativa de Gomes e Sousa (2017), em que se encontrou uma menor quantidade de produções fenomenológicas sobre as vivências de luto, havendo uma ênfase nas experiências de pacientes oncológicos e de seus familiares. Freitas (2018) afirma que, no campo da psicologia fenomenológica-existencial, as pesquisas sobre luto são recentes. Essa certificação remete à necessidade de investigações sobre o fenômeno luto, contribuindo com o desenvolvimento da área.

No campo da praxe profissional, Azevedo e Pereira (2013) afirmam que a clínica psicológica contemporânea se depara cada vez mais com o sofrimento decorrente da experiência de luto, havendo um aumento significativo dessa demanda. Essa constatação nos direciona para a importância de análises científicas sobre o luto, colaborando para a atualização dos profissionais que lidam com pacientes enlutados.

Conforme o que foi exposto anteriormente, a investigação norteou-se pela busca de compreender as vivências de sofrimento de mães que perderam seus filhos. A pesquisa

Rev. Nufen: Phenom. Interd. | Belém, 11(1), 39-54, jan. - abr., 2019. 
enfocou os elementos intersubjetivos das experiências das colaboradoras, refletindo uma estrutura comum da experiência dolorosa de luto materno.

\section{MÉTODO}

A pesquisa é classificada como qualitativa, em sua abordagem, de método empírico-fenomenológico. A abordagem qualitativa privilegia o estudo da subjetividade, visando compreender os sentidos atribuídos pelos indivíduos. Nesta direção, o método empírico-fenomenológico caracteriza-se como um recurso técnico para investigar as essências das experiências humanas, revelando uma estrutura fenomênica (Creswell, 2010; Giorgi \& Sousa, 2010). A escolha do delineamento justifica-se pela adequação em relação ao objeto de investigação e pela escassez de publicações que utilizem o método fenomenológico empírico, conforme constatado por Moreira e Souza (2016).

Este estudo seguiu os aspectos éticos em pesquisa com seres humanos, conforme as diretrizes do Conselho Nacional de Saúde (CNS), aprovado sob o protocolo número 74029417.1.0000.5077. Assim, iniciou-se a fase de recrutamento das participantes, em que foi utilizada a técnica de amostragem em bola de neve (snowball). Essa técnica permite a exploração por meio de cadeias de referência de possíveis sujeitos. A amostra desta investigação constituiu-se de quatro participantes. Os critérios de inclusão foram: autodeclarar-se mãe com histórico de perda de filha(o) e em sofrimento. A seguir foi descrito o perfil amostral. Usou-se as nomenclaturas P1, P2, P3 e P4, referentes ao termo Participante e sua respectiva ordem.

P1 tem quarenta e um anos, perdeu o filho de vinte e um anos assassinado há dez meses. P2 tem quarenta e seis anos. O filho de dezesseis anos faleceu devido a complicações cirúrgicas no esôfago há dois anos e cinco meses. P3 tem quarenta e três anos e seu filho de vinte e dois anos foi assassinado há quatro anos. P4 tem trinta e seis anos e também teve seu filho falecido aos dezessete anos por assassinado há um ano e nove meses. Em relação ao estado civil, P1 é divorciada, P2 e P3 são viúvas e P4 é casada. Todas as participantes são de classe média e residem em uma cidade no estado de Goiás.

Duas entrevistas caracterizadas como fenomenológicas de cunho aberto foram realizadas com cada participante, com duração de aproximadamente trinta minutos. A entrevista iniciou-se com a seguinte questão norteadora: "Me fale sobre seu sofrimento no luto materno". Essa questão inicial se fez presente em todas as entrevistas para todas as participantes. Os dados foram coletados mediante gravador sonoro e transcritos literalmente em editor de texto.

A análise do material deu-se mediante o método empírico-fenomenológico desenvolvido por Amadeo Giorgi, seguindo os quatro passos propostos: estabelecimento do sentido geral, delimitação dos elementos significativos da experiência, transformações das

Rev. Nufen: Phenom. Interd. | Belém, 11(1), 39-54, jan. - abr., 2019. 
unidades de significado em expressões de caráter psicológico e determinação da estrutura geral dos significados (Giorgi \& Sousa, 2010).

O estabelecimento do sentido geral refere-se à leitura de toda a descrição do material, visando captar o sentido do todo. O segundo passo, delimitação dos elementos significativos, refere-se à discriminação das unidades de significado. A transformação das unidades de significado em expressões de caráter psicológico consiste na modificação das expressões do indivíduo em linguagem científica, ou seja, há um emprego de sentido psicológico. O último passo consiste na busca de sintetizar as unidades de significado invariantes, formando a estrutura da experiência (Giorgi \& Sousa, 2010).

\section{RESULTADOS E DISCUSSÃO}

A análise do material empírico evidenciou sete constituintes essenciais, com as seguintes denominações: alterações e dificuldades no viver; desespero; dor; sentimento de arrependimento e culpa; sentimentos negativos despertados pelas lembranças; perda de um modo de existir e perda do sentido do mundo-da-vida. As nomeações das unidades foram baseadas na literatura fenomenológica. A seguir, as unidades serão apresentadas e refletidas fenomenologicamente.

\section{Alterações e dificuldades no viver}

Esta unidade de significado diz respeito às alterações no cotidiano das participantes, com dificuldades no viver. Refere-se a obstáculos enfrentados na higienização pessoal, na alimentação, no sono e em afazeres domésticos. P1 exemplifica essa unidade dizendo que "(...) a gente esquece de tomar banho, de comer, esquece de escovar os dentes". P2 fala das dificuldades para dormir e a necessidade de medicalização. Para ela: "Eu tomo remédio antidepressivo para dormir e tudo". A seguir, outras descrições serão apresentadas, exemplificando essa unidade.

Eu tinha um problema muito sério com a comida, porque quando eu dou essas crises eu não consigo comer, porque quando ele estava doente ele parou de comer; quando ele estava falecendo, ele não estava mais comendo. (P2) Falta de sono que você não consegue dormir direito; você tenta dormir, mas não consegue. Você vira de um lado, vira para outro, você aperta o travesseiro, você levanta, você anda e o sono não vem. Porque, mesmo com os remédios, eu não conseguia dormir. Aí acaba o efeito dos remédios e eu ficava com o corpo mole, mesmo com o remédio eu não dormia. Dava uma cochilada de umas três horas, acordava e não dormia mais, mesmo com a medicação. (P3)

(...) você não sente nem o gosto pela comida, pelo alimento. Você perde o paladar, você perde o olfato, você perde tudo. Eu não comia, era forçada. Eu fiquei assim, porque nos primeiros momentos, aquela primeira semana eu não conseguia comer, nem água sentia falta. (P4) 
(...) é o momento que você não tem força para nada, você não consegue organizar sua vida, você não consegue pensar em nada, nem cuidar de ninguém, nem mesmo de você, muito menos das pessoas à sua volta. Então assim, uma coisa simples que era tomar um banho você estava com dificuldade, você tem dificuldade, você sofre. (P4)

P2 fala da dificuldade em se alimentar. Ela justifica dizendo que, devido à neoplasia esofágica do filho e a dificuldade dele em alimentar-se sem uso de recursos médicos, ela rememora estes episódios que obstruem sua vontade de comer. P3, após a morte do filho, apresenta distúrbios de sono, que, mesmo com o uso de medicação, não apresentam melhora significativa. Ela também apresenta dificuldades na alimentação, dizendo que "(...) fico triste, fico quieta, não converso, perco a fome". P4 rememora que, nos momentos iniciais após a perda, teve dificuldades na alimentação e ingestão de água, bem como nos afazeres domésticos. Essas experiências demonstram que a perda de um filho provoca uma desorganização no mundo-da-vida, com alterações e dificuldades no viver.

Freitas et al. (2015) afirmam que, com a perda, os modos habituais de ser se desestabilizam, o que significa que, quando um filho morre, o modo de ser mãe se esvai. Nesse dissipar, restam as dificuldades na alimentação, na higienização, no sono e nas atividades domésticas, como descrito pelas colaboradoras desta pesquisa. Assim, as modificações no cotidiano apontam para a ausência do filho, para um mundo de impossibilidades (Freitas \& Michel, 2015).

Azevedo e Pereira (2013) afirmam que, na experiência de luto, o indivíduo busca uma reorganização no seu viver. É preciso um tempo, inespecífico e singular, para que haja ressignificação e organização do mundo-da-vida, o que não significa superação. Nessa condição, resta ao enlutado crise no viver, como aponta Freitas (2013) ao dissertar o luto como crise de sentido. As dificuldades cotidianas anunciam a presença do filho como sofrimento encarnado no viver.

\section{Desespero}

A sensação de desespero emergiu como experiência no luto materno. A seguir, algumas descrições da unidade serão apresentadas.

Assim, aquele momento de desespero mesmo; minha alma tremia, eu desmaiava, porque eu sou hipertensa. E todo mundo, as pessoas ficavam me segurando, eu não conseguia caminhar sozinha (...). Aí bate um desespero. Aí, nessa dor que às vezes eu saio sozinha, vou parar lá no cemitério, no túmulo dele, choro, choro e choro. (P1)

Aí foi um desespero, desespero. Você não sabe muito o que faz, você não sabe se quer ir para lá, se quer ajudar. Os médicos não deixam, estão dentro da sala, não pode. E você naquele desespero pedindo, ajoelhando, implorando para eles deixarem ver seu filho e eles não deixam. (P3) 
P1 descreve que "sua alma tremia" ao caracterizar seu desespero, verbalizando episódios de síncope e choro no túmulo do seu filho. P2 também se refere ao choro, dizendo "(...) eu tenho crises de choro incontroláveis, choro, choro e choro". P4 também descreve seu desespero:

Eu acordava à noite com crise de choro, eu ia deitar eu chorava alto, aquelas crises mesmo de soluçar. Eu tinha vontade de quebrar tudo, aquela crise de ansiedade que você quer quebrar tudo, era eu. Eu ficava assim, eu me sentia desse jeito. Aí vem aquele desespero, você fica louca, você quer sair doida na rua. É uma coisa assim de loucura mesmo, você fica como se tivesse louca.

Freitas e Michel (2015), ao sintetizarem os resultados de suas pesquisas sobre luto materno, encontraram o desespero como um constituinte essencial, confirmando os resultados desta pesquisa. Para os autores, o desespero pode estar relacionado com um esvaziamento da vontade de viver ou com uma sensação de enlouquecimento, como P4 apresenta, se expressando por meio de choros, gritos e outras expressões do sofrimento.

Alarcão, Carvalho e Pelloso (2008), em suas investigações fenomenológicas, constataram o desespero de mães pela morte dos filhos devido ao homicídio. Na presente pesquisa, três mães perderam seus filhos devido a situação violenta, mais especificamente o assassinato. Deste modo, os resultados se compatibilizam com os dos referidos autores.

O desespero encontrado sugere o sofrimento como expressão do luto materno, sendo reflexo do abrupto rompimento da relação eu-tu. Com a perda do mundo compartilhado entre mãe e filho, instala-se o caos, o desespero.

\section{Dor}

A experiência de dor foi verbalizada pelas participantes como um fenômeno insuportável. P1 afirma que a dor do luto materno se inscreve na alma, sendo que não há remédio e nenhum recurso médico para amenizar este sentimento. Ela diz:

Nossa, dói na alma da gente. É uma dor que não existe remédio. Qualquer dor tem remédio, você toma remédio, você vai no médico, mas essa dor, não. Eu posso ir no melhor médico do mundo que ela não vai passar. (P1)

P2 apresenta a dor como uma constante em sua vida, como uma presença que evidencia a ausência do filho. Para ela: "É uma forma constante, é uma dor constante, que dói a cada momento, a cada dia". Ela continua descrevendo sua experiência dolorosa: "É doloroso, complicado, sufocante, angustiante. Se resume tudo em uma dor. É uma dor que como o povo fala, igual a dor do parto, só passando para você saber. É uma dor única, um sentimento único". Para P3:

Rev. Nufen: Phenom. Interd. | Belém, 11(1), 39-54, jan. - abr., 2019. 
Não tem nem como descrever aquela dor, aquele aperto que dá, sensação de inchaço, do coração inchado, doendo, dá aquela dor. Eu já consultei, já falei para o médico que estava sentindo uma dor no coração e ele disse que coração não dói. (P3)

Na fala de P3 percebe-se o inominável que é a dor e a metáfora de um coração inchado e dolorido. Ela diz que "é aquela dor por dentro, aquele sufocamento. Na hora parece que o coração da gente está inchado. Me sufoca, parece que eu não dou conta de respirar, tapa tudo assim, fico sufocada". Para P4, "a dor no coração, aquele aperto tão grande, a dor na alma. Você sente sua alma ferida, acabada". Ela continua:

(...) você sente aquela dor lá dentro, que seu coração dói, fica doendo como se tivesse alguma coisa furando, apertando. É uma dor muito grande, é aquela dor que você sente na pele, em tudo, tudo em você dói, até o cabelo dói.

A dor no luto materno não se refere somente ao campo emocional - ela integra o corpo nas expressões físicas, como dificuldades para respirar, dores no peito, no andar curvado e outras reverberações do sofrimento, como em resultados nas pesquisas de Freitas \& Michel (2015). Semelhantemente, na revisão sistemática de Barbosa et al. (2011) há referência de dores emocionais e físicas. Elucida-se, portanto, a repercussão da dor na totalidade do ser-mãe. É uma dor em todo o ser.

Sentimentos de profunda tristeza foram encontrados no estudo de Andrade, Mishima-Gomes e Barbieri (2017) com mães enlutadas, o que sugere a vivência da dor. Dados semelhantes de Almeida, Garcia-Santos e Haas (2011) apontam para incidência maior de tristeza e depressão agitada em mães que perderam filhos por morte súbita, em uma proporção de sessenta e três por cento vírgula sessenta e três por cento $(63,63 \%)$ da amostra estudada. Aqui, referimo-nos a tristeza, depressão e correlatos ao que chamamos de dor, uma expressão do sofrimento.

Outros achados, como em Freitas e Michel (2014), elucidam que a dor é singular e não é circunstancial ao modo da perda, o que designa que, no luto materno, a dor é expressão central, como apontado por Freitas et al. (2015). Perder um filho é uma dor na alma, como dizem as participantes deste estudo. Portanto, essa unidade de sentido nomeia o sofrimento materno de perda com repercussão física e emocional.

\section{Perda de um modo de existir}

Esta unidade refere-se a uma perda do modo habitual de existência da mãe. Perde-se não só o filho, mas perde-se a si mesmo, perde-se o 'nós', perde-se a relação. Todas as participantes referiram-se que, com a morte do filho, uma parte de si foi perdida. P3 fala

Rev. Nufen: Phenom. Interd. | Belém, 11(1), 39-54, jan. - abr., 2019. 
que “(...) foi embora, partiu, é um pedaço de você que foi embora (...). Esse pedaço é o filho da gente, que saiu da gente, de dentro da gente". Na fala de P1 há uma comparação com o cordão umbilical, sendo que, para ela, a morte do filho assemelha-se à ruptura umbilical. Segundo ela, "é perder um pedaço da gente, é difícil demais. É como você perder a sua própria vida. É como se eu tivesse cortado o cordão umbilical de novo, a gente sente que o coração da gente saiu a metade".

Na exposição de P2, filho é parte da mãe e, com sua ida, uma parte materna também se esvai. Ela metaforiza e diz que é como se tivesse perdido algum membro do corpo, como o braço ou a perna, referindo-se a uma falta radical.

(...) é como se faltasse algo em você, é como se você perdesse uma parte do seu corpo. Você sempre está sentindo aquela falta. É uma coisa que machuca, não sei, é como se faltasse um braço, uma perna, falta uma coisa em você. Você sempre está incompleta. Você perde uma parte do seu corpo. Você sente como se faltasse, uma falta realmente. É um pedaço da gente, filho é um pedaço da gente. (P2)

Assim como P3, P4 também traz a metáfora da dilaceração de uma parte do corpo, bem como refere-se à mudança na sua identidade, no seu modo de ser-no-mundo. Ela expressa que a mulher que era sorridente e que gostava de dançar e sair, morreu.

Então assim, desde que meu filho morreu, metade minha foi. Mas assim, é uma coisa, é tipo você ter um braço normal, você está trabalhando e você perde ele. Você tem que aprender, você tem que reaprender a viver sem o braço. É assim, é como se naquele momento você morresse. (P4)

E como se metade de mim morresse naquele dia que meu filho morreu, uma parte morreu. Então eu tenho uma parte, ficou uma parte ruim. Eu era uma mulher muito alegre. Se você tivesse me conhecido antes, você veria eu era muito alegre, sempre sorridente, sempre. Eu gostava de dançar, eu fazia um monte de coisa, saía todo final de semana. Então isso acabou aqui, naquele dia, entendeu? Aquela mulher morreu. (P4)

Essa unidade está no âmago do conceito de luto para a fenomenologia existencial baseada na perspectiva merleau-pontyana. O luto é compreendido como uma ruptura na relação, em que, com a supressão abrupta do tu, o eu também morre, pois este só é existente em uma relação específica, não sendo uma entidade independente. Assim, com a desaparição do outro, o sobrevivente desorganiza seu modo de ser-no-mundo habitual, ou seja, há uma perda no modo de existir (Freitas, 2013; Freitas et al., 2015; Freitas, 2018; Michel, 2017).

Ao expressarem que a morte do filho se assemelha à falta de um membro do corpo, as participantes se referem à desorganização no seu modo de ser, uma perda no modo 
de existência. Assim, percebe-se o eu sem a presença habitual do tu, sendo necessária uma ressignificação da relação, um novo modo de estar-com, agora com uma presença-ausente.

\section{Perda do sentido do mundo-da-vida}

O luto traz consigo uma perda de sentido no viver. A vida parece ter perdido a cor e o que resta é um sentimento de vazio, de falta. É este o sentido que as participantes revelaram no processo de inquirição ao descrevem suas experiências de luto materno. P1 fala desta perda de sentido ao descrever um vazio. Segundo ela, "é um vazio muito grande, nossa, muito grande mesmo. Aí esse vazio vai ficar para sempre. Não tem nada que vai preencher ele. Aí a gente vai aprender a conviver com a saudade, com a ausência".

Para P2, a perda de um filho provoca uma sensação de sufoco, de vazio, de falta. Ela diz: "(...) é uma coisa que sufoca, é uma coisa assim, é difícil explicar essa dor, é uma falta, é um vazio. É uma falta que eu acho que não tem como preencher esse vazio". Segundo $\mathrm{P} 3$, perde-se o ânimo, a esperança de viver, pois "você perde as forças, não têm ânimo para lutar, para correr atrás de nada mais, vai perdendo a esperança". A seguir, serão descritos os significados de P4.

Porque assim, você não sente nada, você não sente vontade de nada. É como se o mundo ficasse escuro, cinza, perdesse a cor. Tudo acabou na sua vida, aí você tem que acostumar, você tem que ir aprendendo. Todo dia é um sofrimento novo, não é uma alegria. O povo fala assim que o tempo ajuda, mas neste caso de perda de filho, tempo não é favorável, ele é pior. (P4)

P4 caracteriza o luto como um mundo cinza, sem cor, sem alegria. O tempo, segundo ela, é condição que agrava o sofrimento. Neste aspecto, não há sentido, há falta. $A$ literatura sobre luto demostra que, com a perda de um filho, rompe-se com os sentidos do mundo-da-vida da mãe, sendo que este significado é um dos fundamentos da experiência de luto, provocando revisão de valores, vazio, sentimentos de desamparo, de solidão existencial, de esvaziamento dos sentidos da vida, falta de perspectivas e outros sentimentos semelhantes (Almeida et al., 2011; Freitas \& Michel, 2014; Freitas \& Michel, 2015; Freitas et al., 2015; Michel, 2017; Santos \& Sales, 2011; Silva \& Melo, 2013).

A perda de sentido decorre da desaparição do filho, de uma ruptura brusca com o tu. Deste modo, com a supressão da presença do tu, há morte de si, do "nós", rompendo com os sentidos habituais de ser. Posto isso, instala-se a crise de sentido, definição exímia de luto (Freitas, 2013; Freitas et al., 2015; Freitas, 2018). Isso sugere que a perda do sentido do mundo-da-vida se dá como um movimento de confusão e queda, interrompendo perspectivas e certezas.

Rev. Nufen: Phenom. Interd. | Belém, 11(1), 39-54, jan. - abr., 2019. 


\section{Sentimento de arrependimento e culpa}

Esta unidade refere-se aos sentimentos de arrependimento e culpa verbalizados pelas mães participantes. P1 diz que "nossa, eu acho que eu nunca vou me perdoar por eu não ter ficado em casa para eu dar esse abraço nele que faltou”. E prossegue: “(...) mas eu ainda me sinto culpada por não ter conseguido livrar ele da morte, livrar ele desse caminho que ele escolheu". Esse sentimento foi compartilhado pelas outras participantes, como para P2.

Eu me sinto um pouco culpada, se eu estou bem parece que eu me sinto 'nossa, eu não posso ficar bem'. Parece que eu me sinto culpada de rir, de ser feliz. Se eu tiver em um lugar rindo, eu me sinto mal. (P2)

$\mathrm{Na}$ fala de P2, percebe-se um sentimento de culpa ao se sentir alegre, sorridente. Para P3, a morte do filho evidenciou que muitas coisas poderiam ter sido feitas por ele. sentimento de arrependimento e culpa, para ela, também está atrelado a não poder ter ajudado o filho na hora do crime, em seus últimos instantes de vida. Ela relata o desejo de ter morrido no lugar dele.

Eu não estava ali, se eu tivesse ali para ajudar ele não... Aí eu fico pensando, na hora que ele mais precisou de mim, eu não estava lá. Eu podia estar lá para ajudar, eu podia ter levado esse tiro no lugar dele. A gente pensa tanta coisa (...). Porque ele morreu muito cedo, ficou em falta muita coisa que a gente podia fazer para ele. (P3)

Para P4, o arrependimento e a culpa relacionam-se com os últimos momentos de seu filho, em sua sala, pois ela não permaneceu com ele até sua morte. Segundo ela: "Me arrependo as vezes de não ter ido lá, de não ter ficado até o último minuto lá dentro com ele. Eu me arrependo de não ter ficado ali segurando ele, a mão dele até ele morrer".

No tocante às descrições, segundo Kovács (1992) o sentimento de culpa em relação à morte do outro é frequente. A autora salienta que, mesmo que se compreenda racionalmente o fato, no campo dos sentimentos a culpa é experienciada. Em Freitas e Michel (2015) há alusão de que as mães apresentam a crença de que poderiam ter evitado a morte do filho, culpando-se por isso, como é o caso de P1 e P3.

Outros dados da literatura trazem que a culpabilização pela morte do filho é frequente, o que gera sofrimento (Freitas \& Michel, 2014). Os dados da pesquisa de Almeida et al. (2011) e Andrade et al. (2017) também descrevem o sentimento de culpa em mães enlutadas. Sendo assim, o sofrimento no luto materno parece compreender vivências de arrependimento e culpabilização, como constatado pelas participantes deste estudo.

\section{Sentimentos negativos despertados pelas lembranças}

Rev. Nufen: Phenom. Interd. | Belém, 11(1), 39-54, jan. - abr., 2019. 
As lembranças do filho, para as participantes, são fontes de sofrimento. P1 descreve esta unidade ao dizer que: "Nossa, não é fácil; nossa, todo momento a gente lembra que ele não está aqui, mais". Para P2, datas comemorativas ou situações a fazem lembrar do filho, causando-lhe sentimentos negativos. Ela verbaliza que o filho é uma presença muito constante em sua vida. A seguir, essa significação será descrita.

De repente já me dá, vem aquela... um objeto, uma música, uma comida, um som, aí já vem a lembrança dele. Aí é como se jogasse uma água em cima de mim e apaga tudo (...). Esses dias mesmo eu fiquei muito ruim, duas semanas de hospital, porque passou o Natal eu já estava meio ruim, aí veio o aniversário dele. Então é uma presença muito presente que eu tenho dele. (P2)

Assim, muitas vezes eu estou no meu serviço de boa, aí de repente entra um rapazinho, aí na hora eu lembro "nossa, meu filho poderia estar deste jeito". Eu vejo o coleguinha dele na rua, um momento assim, uma lembrança muito...Quando eu saio do meu horário de almoço, que eu vou embora, os meninos estão saindo da escola. Então aquilo ali não tem como lembrar, não tem como esquecer, não tem como não lembrar. (P2)

Os sentimentos negativos despertados pelas lembranças de P3 a fazem se sentir com uma sensação corporal de flutuar. Ela diz: "Eu andava era como se tivesse com a cabeça grandona, aquele trem mais esquisito, parece que estava flutuando. E só lembrando do meu filho, do meu filho". Ela continua sua descrição:

É igual eu falei, tem vez que eu estou em um mês depressiva, pensando muito, aí a gente fica pensando nas coisas ruins. Ao invés de pensar nas coisas boas, a gente fica pensando nas coisas ruins, não lembra nada de bom, só das ruins. Vai ficando magoada, sentida, vai dando aquele aperto, aquele sufocamento. Aí parece que se eu não chorar vou cair e morrer, aquele trem mais esquisito do mundo. (P3)

As lembranças do filho de P4 são constantes em sua vida, inclusive em seus afazeres conscientes e na sua vida onírica. Ela descreve sentimentos negativos em relação a estas rememorações.

(...) eu levanto, eu lembro do meu filho; eu vou tomar um café, eu estou lembrando do meu filho; eu vou almoçar, eu lembro; no jantar, no deitar, até dormir, eu estou sempre lembrando dele. É horrível, tipo triste, muito triste. É sempre você estar lembrando da pessoa, não tem como eu não lembrar do meu filho, desde a hora que eu deito até a hora que eu levanto, até entre os sonhos eu estou vendo ele, eu estou lembrando dele. (P4)

As recordações são formas de presença, são a anunciação de uma falta presentificada. A presença-ausente do filho se dá nas memórias, como Freitas (2018) afirma ao dissertar que o falecido se apresenta nas vivências do sobrevivente por meio de lembranças, objetos, fotos e outras formas de presença.

Rev. Nufen: Phenom. Interd. | Belém, 11(1), 39-54, jan. - abr., 2019. 
Este achado é semelhante aos de Alarcão et al. (2008) ao descreverem que as lembranças do filho para as mães são tidas como insuportáveis, visto que os sentimentos e o sofrimento são revividos. Há relatos também de pesadelos e imagens intrusivas por Almeida et al. (2011).

No tocante a esta unidade, há contraposições na literatura, dado que alguns resultados apontam que as mães apresentam um apego às memórias dos filhos, visando sua perpetuação, como em Barbosa et al. (2011), Freitas e Michel (2014) e Freitas e Michel (2015). Inclusive na pesquisa de Alarcão et al. (2008), já exposta, em que há referência das lembranças como insuportáveis, há também indicação de apego às memórias como forma de conexão com o filho falecido. Na amostra deste estudo não se evidenciou essa ligação, mas sim a expressão de sentimentos negativos referentes às lembranças.

\section{CONCLUSÃO}

A morte é um fato cotidiano. Como presença na vida, sua constância nos assola. Com o objetivo de compreender o sofrimento no luto materno, esta pesquisa se debruçou no mundo-da-vida de quatro mães, perscrutando suas vivências. Como aporte teóricometodológico, recorremo-nos à fenomenologia, na busca de desvelar os sentidos do luto enquanto condição da humanidade. As entrevistas fenomenológicas mostraram-se como espaço de escuta da dor, em um movimento reflexivo em direção à essência de um novo jeito de ser mãe.

Os resultados evidenciaram uma estrutura vivencial, em que os constituintes essenciais refletem o âmago do fenômeno do luto materno, em seu recorte de sofrimento. Estes constituintes foram: alterações e dificuldades no viver, desespero, dor, sentimento de arrependimento e culpa, sentimentos negativos despertados pelas lembranças, perda de um modo de existir e perda do sentido do mundo-da-vida.

Estes achados demostram uma ruptura na habitualidade do ser-mãe, demandando ressignificação para um novo modo de ser-com, de ser-mãe-de-filho-morto. Por isso, o luto não deve ser compreendido como um processo fásico ou como um estado patológico. A fenomenologia existencial de base merleau-pontyana o entende como uma condição existencial, como um novo modo de ser. A clínica do luto demanda, porém, acolhimento e ressignificação e não superação de fases pré-estabelecidas e minimização de possíveis sintomas.

A descrição dos resultados leva-nos à conclusão de que o luto materno é uma experiência de intenso sofrimento, com repercussões físicas e emocionais. Assim, a dor do luto se dá na totalidade da mãe, em todo o seu ser-no-mundo. Com a perda, o filho anunciase como presença-ausente. Ausente, pois não se está mais no campo existencial da mãe, em sua materialidade corpórea, porém, presente nas lembranças, nas alterações do cotidiano,

Rev. Nufen: Phenom. Interd. | Belém, 11(1), 39-54, jan. - abr., 2019. 
nos sentimentos despertados pela morte e na perda do sentido e do modo de existir. Em suma, a presença do ente falecido se revela no sofrimento, pois é este o indicativo de que o filho se faz presente.

Os resultados da pesquisa apontam a necessidade de se pensar no suporte para as mães enlutadas, visto seu intenso sofrimento. Deste modo, uma agenda a ser pensada nas políticas públicas, por exemplo, abre-se como possibilidade. No campo da psicologia fenomenológica, delineia-se a indispensabilidade de uma clínica do luto, capaz de promover a escuta da dor de ser mãe-de-filho-morto, permitindo um espaço que promova ressignificação.

O estudo apresentou limitações no que se refere ao foco das experiências e quanto à localidade da coleta de dados. Por isso, no campo das investigações científicas, novos estudos poderão objetivar compreender o contexto familiar mediante a perda, bem como as experiências no luto paterno e infantil. Sugere-se estudos com indivíduos de diferentes regionalidades do país, a fim de melhor validação dos resultados.

\section{REFERÊNCIAS}

Alarcão, A. C. J., Carvalho, M. D. B. \& Pelloso, S. M. (2008). A morte de um filho jovem em circunstância violenta: Compreendendo a vivência da mãe. Revista Latino-Americana de Enfermagem, 16(3), 341-347. doi: 10.1590/S0104-11692008000300002

Almeida, E. J., Garcia-Santos, S. \& Haas, E. J. (2011). Padrões especiais de luto em mães que perderam filhos por morte súbita. Revista de Psicologia da IMED, 3(2), 607-616. doi: $10.18256 / 2175-5027$

Andrade, M. L., Mishima-Gomes, F. K. T. \& Barbieri, V. (2017). Recriando a vida: O luto das mães e a experiência materna. Revista Psicologia: Teoria e Prática, 19(1), 21-32. doi: $10.5935 / 1980-6906$

Arantes, A. C. Q. (2016). A morte é um dia que vale a pena viver. Rio de Janeiro, RJ: Casa da Palavra.

Azevedo, A. K. S. \& Pereira, M. A. (2013). O luto na clínica psicológica: Um olhar fenomenológico. Revista Clínica e Cultura, 2(2), 54-67. Recuperado em 15 de janeiro de 2018, de https://seer.ufs.br/index.php/clinicaecultura/article/view/1546/1695

Barbosa, C. G., Melchiori, L. E. \& Neme, C. M. B. (2011). Morte, família e a compreensão fenomenológica: Revisão sistemática da literatura. Psicologia em Revista, 17(3), 363377. Recuperado em 20 de janeiro de 2018, de http://pepsic.bvsalud.org/ scielo.php?script=sci_arttext\&pid=S1677-11682011000300003

Berten, A. (2010). Dizer o sofrimento: Fenomenologia, cognitivismo, pragmática. Psicologia em Revista, 16(2), 221-250. Recuperado em 05 de fevereiro de 2018, de http://pepsic.bvsalud.org/scielo.php?script=sci_arttext\&pid=S1677-11682010000200002

Bromberg, M. H. P. F. (2000). A psicoterapia em situações de perdas e luto. Campinas, São Paulo: Livro Pleno.

Rev. Nufen: Phenom. Interd. | Belém, 11(1), 39-54, jan. - abr., 2019. 
Creswell, J. W. (2010). Projeto de pesquisa: Métodos qualitativo, quantitativo e misto. Porto Alegre, Rio Grande do Sul: Artmed.

Freitas, J. L. (2013). Luto e fenomenologia: Uma proposta compreensiva. Revista da Abordagem Gestáltica, 19(1), 97-105. Recuperado em 20 de abril de 2017, de http://pepsic.bvsalud.org/scielo.php?script=sci_arttext\&pid=\$1809-68672013000100013

Freitas, J. L. (2018). Luto, pathos e clínica: Uma leitura fenomenológica. Revista Psicologia USP, 29(1), 50-57. doi: 10.1590/0103-656420160151

Freitas, J. L. \& Michel, L. H. F. (2014). A maior dor do mundo: O luto materno em uma perspectiva fenomenológica. Psicologia em Estudo, 19(2), 273-283. doi: 10.1590/1413737222324010

Freitas, J. L. \& Michel, L. H. F. (2015). A vivência do luto materno: Um olhar fenomenológico-existencial. Em J. L. Freitas \& M. V. F. Cremasco (Orgs.). Mães em luto: $A$ dor e suas repercussões existenciais e psicanalíticas (pp. 25-44). Curitiba, Paraná: Juruá.

Freitas, J. L., Michel, L. H. F. \& Zomkowski, T. L. (2015). Eu sem tu: Uma leitura existencial do luto em psicologia. Em J. L. Freitas \& M. V. F. Cremasco (Orgs.). Mães em luto: A dor e suas repercussões existenciais e psicanalíticas (pp. 15-24). Curitiba, Paraná: Juruá.

Giorgi, A. \& Sousa, D. (2010). Método fenomenológico de investigação em psicologia. Lisboa, Portugal: Fim de século.

Gomes, D. M. \& Sousa, A. M. (2017). A morte sob o olhar fenomenológico: Uma revisão integrativa. Revista do Nufen, 9(3), 164-176. doi: 10.26823/RevistadoNUFEN.vol09. n03revir25

Kovács, M. J. (1992). Representações de morte. Em M. J. Kovács (Org.). Morte e Desenvolvimento humano. São Paulo, SP: Casa do Psicólogo.

Merleau-Ponty, M. (1999). Fenomenologia da percepção. São Paulo, SP: Martins Fontes. (Original publicado em 1945).

Michel, L. H. F. (2017). A vivência de psicoterapia de mães enlutadas (Dissertação de mestrado). Recuperado em 02 de agosto de 2018, de https://acervodigital.ufpr.br/handle/1884/47461

Moreira, R. B. \& Souza, A. M. (2016). Contribuições do método fenomenológico empírico para estudos em psicologia no Brasil: Revisão integrativa da literatura. Revista do Nufen, 8(1), 01-12. Recuperado em 25 de abril de 2018, de http://pepsic.bvsalud. org/scielo.php?script=sci_arttext\&pid=S2175-25912016000100002

Santos, E. M. \& Sales, C. A. (2011). Familiares enlutados: Compreensão fenomenológica existencial de suas vivências. Revista Texto e Contexto Enfermagem, 20(Esp), 214-222. doi: 10.1590/S0104-07072011000500027

Silva, P. K. S. \& Melo, S. F. (2013). Experiência materna de perda de um filho com câncer infantil: Um estudo fenomenológico. Revista da Abordagem Gestáltica, 19(2), 147-156. Recuperado em 02 de março de 2018, de http://pepsic.bvsalud.org/scielo. php?script=sci_arttext\&pid=S1809-68672013000200002 